\title{
Impact of NABARD's Refinance Operations on the Beneficiaries in Chittoor District of Andhra Pradesh State, India
}

\author{
K. Muneendra ${ }^{1}$, Dr.C.Swarajya Lakshmi ${ }^{2}$ \\ ${ }^{I}$ Research Scholar, Department of Commerce, S.V. University, Tirupati, A.P. India. \\ ${ }^{2}$ Rsearch Supervisor, Department of Commerce, S.V. University, Tirupati, A.P. India.
}

\begin{abstract}
The creation of NABARD was a part of the post-Independence Nehruvian vision of institution building carried forward by Indira Gandhi, who dedicated it to the nation on 5 November 1982. to erect a strong public policy institution in rural credit for building a strong rural India. The significance of rural credit as a critical input to agriculture and allied activities is reinforced by the unique role of Indian agriculture in the macro-economic framework and its role in poverty alleviation. The Financial institutions in the Chittoor District viz., Commercial Banks, Chittoor District Central Cooperative Banks and Sapthagiri Grameena Banks have been involved in lending to specific purposes and schemes for which $N A B A R D$ has been providing refinance. To assess the impact of refinance operations of NABARD on the beneficiaries, in relation occupation, income, and financial position. An empirical analysis is conducted on the data collected with the use of structured schedule. The analysis of the data revealed that, the access of farm and non farm credit by rural populace has been increased in recent years. Furthermore that there is significant growth in the income and financial position of beneficiaries after availing loans from different financial institutions in the Chittoor District under the refinance if NABARD.
\end{abstract}

Keywords: Agricultural credit, NABARD, Refinance, Rural credit, Rural development,

\section{Introduction}

NABARD was created in response to the aspirations of the people and Government of India to create a strong public policy institution in rural credit for building a strong rural India and accordingly, NABARD flagged capital formation in rural economy as the thrust area. From its inception NABARD is providing finance for agriculture and rural development under various schemes through different financial institutions in the name of refinance support. It replaced the Agricultural Credit Department (ACD) and Rural Planning and Credit Cell (RPCC) of Reserve Bank of India, and Agricultural Refinance and Development Corporation (ARDC). It is one of the premier agencies providing developmental credit in rural areas. NABARD is India's specialized bank for Agriculture and Rural Development in India. In the last 30 years, NABARD has built itself up into a unique institution. One could hardly find an institution of a similar nature in the banking sector anywhere else in the world. It combines the roles of a central bank, a development agency, a financial institution, an infrastructure funding agency, a microfinance institution, a planning board and an apex-level policymaker ${ }^{[1]}$. The majority of India's rural poor remain dependent on agriculture for their primary source of income and majority of them are marginal and small farmers, whereas the poorest among them are landless ${ }^{[2]}$. Adequate availability of credit on time is an important requirement for the rural people, particularly under conditions of scarcity of resources and uncertainty. Previous experiences of financial institution show that small credits have proven feasible of lending to the poor for the rural development.

For many years, financial institutions viz. Commercial Banks(CBs), Chittoor District Central Cooperative Banks(CDCCBs) and Sapthagiri Grameen Banks(SGBs) in the Chittoor District of Andhra Pradesh state have been providing credit to the farmers, rural artisans and small business men under different schemes for which NABARD is giving refinance support to them. Earlier, several studies have been undertaken to assess the impact of refinance operations of NABARD by individual researchers, financial institutions, Committees, Commissions and Government. But area specific studies are comparatively very limited in number. In a vast country like India with varying agro-climatic and socio-economic conditions, location specific studies are required. It is indispensable to assess the impact of NABARD's refinance operations on the beneficiaries of above said financial institutions in Chittoor District, with a view to provide necessary information to the bankers and government about changes in income and assets of the rural people which will assist them in further policy making and to show the impact of refinance operations of NABARD in elimination of rural poverty. Though the study is restricted to Chittoor district of Andhra Pradesh State, the conclusions of the study is will be relevant to all districts or areas with similar agro-climatic and socio-economic conditions. 


\section{Review Of Literature}

Anwarul Hoda, and Prerna Terway (2015), in their research paper "Credit Policy for Agriculture in India - An Evaluation", mentioned that a targeted debt relief is an appropriate response for alleviating farmer distress and cannot be criticized for vitiating the environment for loan operations in future. The Prime Minister's rehabilitation program for suicide-prone districts was doubly beneficial as it combined debt relief with a public investment and private investment program mainly in irrigation and horticulture. The loan waiver scheme of 2008 was followed by another loan waiver of a large magnitude called "Runa Mafi", in 2014 in the state of Andhra Pradesh and the newly formed state of Telangana. Despite several warnings and criticism from the Reserve Bank of India and the Indian Banking Association, the scheme was rolled out in these two states. While it will cost Rs. 40000 crore in Andhra Pradesh, it is expected to cost Rs. 17000 crore in Telangana ${ }^{[3]}$.

Dr.V.J.R Emerlson Mosses and Mr. G. Krishnamoorhty(2014), in their piece of writing "Impact of Microfinance and SHG - An Overview", revealed that levels of poverty are high and because of this problem Self Help Groups movement occupies a significant agenda in the poverty reduction and empowerment of poor people. Microfinance program is important institutional device to provide small credit to the rural people in order to alleviate poverty and SHG bank linkage have the potential to minimize the problems of inadequate access of banking services to the poor ${ }^{[4]}$.

R. Uma Devi and S. R. K. Govt(2012), in their article "The Role of Credit Co-Operatives in the Agricultural Development of Andhra Pradesh, India", concluded that the advantages enjoyed be the beneficiaries through improved technology with the efforts of the banks in terms of high production, increased net returns and subsidiary incomes. There is further need to enlighten the farmers about the superiority and profitability of improved technology through the extensive credit services. By and large the role of Credit Cooperatives is highly impressive and clearly exhibited in the socio-economic development gained by the beneficiaries ${ }^{[5]}$.

Shahin Razi (2015), stated in his article "Continued Rural Agenda", that a RIDF has been announced with a corpus of Rs. 25000 crores under NABARD. Also in Pipeline are Rs.15000 crores, Long Term Rural Credit Fund Rs.45000 crores, Short Term Cooperative Rural Credit Refinance Fund Rs.15000 crores, and another Rs. 15000 crores for Short Term RRB Refinance Fund to Revive the Credit line of agriculture in Rural Development Budget $2015-16^{[6]}$.

Veerpaul Kaur Maan and Amritpal Singh(2013), in their research "Role of NABARD and RBI in Agricultural Sector Growth", the Reserve Bank of India has been playing an important role in meeting the country's need in respect of rural credit and in making the position of State Cooperative Banks and Rural Development Banks strong. In order to benefit fully from the services of the Reserve Bank of India, the government must have a properly organized rural banking system. The State Governments have assigned due place to these institutions in the planning process ${ }^{[7]}$.

\section{Objectives}

The present research paper is prepared with certain objectives as mentioned under.

$>$ To assess the impact of NABARD's refinances on the beneficiaries of different financial institutions in the Chittoor District of Andhra Pradesh State.

$>$ To show the impact of refinance operations of NABARD in elimination of rural poverty.

\section{Hypothesis}

$>$ There is no significant variation in the impact of refinance of NABARD on the beneficiaries of different agencies in Chittoor district.

\section{Research Methodology}

To study the stated objectives, Chittoor District was taken as the universe of study. The sample data for the study was collected from the three revenue divisions namely Chittoor, Tirupati and Madanapalle of Chittoor District. Survey method is adopted for the study by using two stage random sampling technique as,

Stage 1: Selection of banks and

Stage 2: Selection of Beneficiaries

All the three revenue divisions of the district are covered for selection of bank branches considerably refinanced by NABARD and the beneficiaries of sample bank branches. In the first stage 30 sample bank branches are selected at 10 per cent of total Commercial Bank branches, Sapthagiri Grameena Bank branches and Chittoor District Central Cooperative Bank branches in three revenue divisions.

In the next stage 192 sample beneficiaries are selected at 5 per cent of total beneficiaries of select Commercial Bank Branches, Sapthagiri Grameena Bank branches and Chittoor District Central Cooperative Bank branches in the district. A structured schedule was administered for the collection of data from the sample 
beneficiaries for the year 2014-15 relating to loan utilization, employment, income and asset position, and repayment of loans to the banks.

\section{Results And Discussions}

Commercial Banks(CBs), Sapthagiri Grameena Banks (SGBs) and Chittoor District Central Cooperative Banks (CDCCBs) have been directed to extend credit through their widespread branch network to priority sectors which include agriculture and its allied activities, village and cottage industries, small scale industries, self-employed persons, retail traders and small business for achieving agriculture and rural development. The impact of NABARD's refinances on the occupation, income and financial status of sample beneficiaries of select bank branches are discussed as in the following sections.

\subsection{Impact of NABARD's Refinance on Sample Beneficiaries of Select Commercial Banks (CBs) 6.1.1 Occupation-wise Loans and Subsidies of Sample Beneficiaries of select CBs}

TABLE 1 demonstrate the loans and subsidies to different occupational borrowers of CBs in Chittoor District in terms of amounts and averages. Out of the total loan utilised, Agriculture accounts for 48 per cent followed by Small Business and Allied Activities with 32 per cent and 19 per cent respectively. Considering the subsidy amount, Small Business got the highest subsidy at 42 per cent of total subsidy, followed by Agriculture and Allied activities at 35 per cent and 22 per cent respectively. The subsidy amount as a percentage of loan amount was the highest in the case of Small Business category at 13.4 per cent and the lowest in the case of Agriculture at 7.49 per cent. Average loan amount borrowed was the highest in the case of Agriculture at Rs.23867 and the lowest in the case of Allied activities at Rs.20106. The average subsidy was the highest for Small Business category followed by Allied activities and Agriculture. On the whole the average amount of loan borrowed is Rs. 10455 , and the average Subsidy is Rs.2255 which is 10.18 per cent of the average loan amount.

\subsubsection{Income Growth of Occupation-wise Sample Beneficiaries of select CBs}

TABLE 2 presents growth in income of occupation-wise sample borrowers of select Commercial Banks in the district. Each borrower on an average had a growth in income of Rs. 4813 which is 45.2 per cent of income before securing loan of Rs. 10647. In the case of agriculture each borrower has a growth in income of Rs.3684 which is 42.86 per cent. While considering the small business each borrower has a growth in income at Rs.6269 or 52.64 per cent and in the case of allied activities it is Rs. 4844 which is 37.39 per cent. In terms of amount, it is noted that among all the occupations small business has recorded the highest growth in income followed by agriculture and allied activities.

\subsubsection{Income Utilisation by Occupation-wise Sample Beneficiaries of Select CBs}

TABLE 3 portrays occupation-wise income utilization by sample borrowers of select CBs in the district. From the income earned by using loan amount, small business borrowers had spent more amounts for repayment of loan at 90.58 per cent of income trailed by borrowers of allied activities and agriculture at 73 per cent and 62.42 per cent respectively. From the income generated by using loan borrowings, borrowers of agriculture had spent more amounts for purchase of assets at 25.08 per cent of income followed by borrowers of allied activities at 19.38 per cent and small business borrowers at 5.01 per cent. With regard to amount spent for ceremonies from the income earned by employing loan amount, borrowers of agriculture had spent more at 12.5 per cent followed by allied activities borrowers at 7.62 per cent and small business borrowers at 4.41 per cent. On the whole the borrowers of all occupations had spent 75.33 per cent of income for loan clearance, 16.49 per cent for purchase of assets and 8.18 per cent for ceremonies.

\subsubsection{Repayment of Loans by Occupation-wise Beneficiaries of Select CBs}

TABLE 4 presents repayment of loans by occupation-wise sample borrowers of select Commercial Banks in the district. The total loan amount of sample borrowers was Rs. 1682500 of which Rs. 1006300 was repaid which is 59.81 per cent and Rs.676200 was outstanding. The borrowers of agriculture category stood first in repayment of loans with 68.33 per cent followed by borrowers of small business at 53.37 per cent and borrowers of allied activities at 49.39 per cent of loan amount. On an average each borrower has utilized loan amount of Rs. 22138 out of which Rs.13241 was repaid and Rs.8897 was outstanding. The data revealed that repayment of loans is better in the case of borrowers of agriculture than in the case of the borrowers of other occupations.

\subsection{Impact of NABARD's Refinance on Sample Beneficiaries of Sapthagiri Grameena Banks (SGBs) 6.2.1 Occupation-wise Loan and Subsidies of Sample Borrowers of select SGBs}

TABLE 5 explains the loans and subsidies to different occupational borrowers of SGBs in Chittoor District in terms of amounts and averages. Out of the total amount of loan utilised, Agriculture accounts for 53 per cent trailed by Small Business and Allied Activities with 30 per cent and 18 per cent respectively. With 
regard to the subsidy amount, borrowers of agriculture category got the highest subsidy at 62.39 per cent of total subsidy, followed by borrowers of small business and Allied activities at 26.4 per cent and 13.22 per cent respectively. The subsidy as a percentage of loan was the highest in the case of borrowers of agriculture category at 19.51 per cent and the lowest in the case of borrowers of allied activities at 12.49 per cent. Average loan amount borrowed is the highest in the case of allied activities at Rs.23914 and the lowest in the case of agriculture at Rs.12884. The average subsidy is the highest for allied activities category followed by agriculture and small business. On the whole the average amount of loan borrowed is Rs. 14667, and the average Subsidy amount is Rs. 2510 which is 17.12 per cent of the average loan amount.

\subsubsection{Income Growth of Occupation-wise Sample Borrowers of select SGBs}

TABLE 6 depicts the growth in income of occupation-wise sample borrowers of the select SGBs in the district. Each borrower on an average had a growth in income of Rs.4102 which is 76.2 per cent of income before securing a loan of Rs. 5383. In the case of agriculture each borrower has a growth in income of Rs.2436 which is 71.38 per cent. While considering the small business each borrower has a growth in income at Rs.5867 or 77.99 per cent and in the case of allied activities it is at Rs.8607 which is 81.36 per cent. In terms of amount, it is noted that among all the occupations borrowers of allied activities recorded the highest growth in income followed by borrowers of small business and agriculture.

\subsubsection{Income Utilisation by Occupation-wise Sample Borrowers of Select SGBs}

TABLE 7 presents the occupation-wise income utilization by sample borrowers of select SGBs in the district. From the income earned by using loan amount, small business borrowers had spent more amounts for repayment of loan at 79.43 per cent of income trailed by borrowers of allied activities and agriculture at 56.98 per cent and 52.26 per cent respectively. From the income generated by using loan borrowings, borrowers of allied activities had spent more amounts for purchase of assets at 43.02 per cent of income followed by borrowers of agriculture at 34.5 per cent and small business borrowers at 15.46 per cent. With regard to amount spent for ceremonies from the income earned by employing loan amount, borrowers of agriculture had spent more at 13.24 per cent followed by small business borrowers at 5.11 per cent while borrowers of allied activities had spent no amount of income. As a whole the borrowers of all occupations had spent 62.89 per cent of income for loan clearance, 30.99 per cent for purchase of assets and 6.12 per cent for ceremonies.

\subsubsection{Repayment of Loans by Occupation-wise Borrowers of Select SGBs}

TABLE 8 presents the repayment of loans by occupation-wise sample borrowers of select SGBs in the district. The total loan amount of sample borrowers was Rs.924000 of which Rs.643700 was repaid which is 69.66 per cent and Rs.280300 was outstanding. The borrowers of small business category stood first in repayment of loans with 72.06 per cent followed by borrowers of agriculture at 68.73 per cent and borrowers of allied activities at 68.58 per cent of loan amount. On an average each borrower utilized a loan amount of Rs.14667 out of which Rs.10217 was repaid and Rs.4449 was outstanding. The data revealed that repayment of loans is better in the case of borrowers of small business than the borrowers of all other occupations.

\subsection{Impact of NABARD's Refinance on Sample Borrowers of Chittoor District Central Cooperative Banks (CDCCBs)}

\subsubsection{Occupation-wise Loan and Subsidies of Sample Borrowers of select CDCCBs}

TABLE 9 demonstrate the loans and subsidies given to different occupational borrowers of select CDCCBs in Chittoor District in terms of amounts and averages. Out of the total amount of loan utilised, Agriculture accounts for 57.19 per cent trailed by Small Business and Allied Activities with 32.06 per cent and 10.75 per cent respectively. With regard to the subsidy amount, borrowers of agriculture category got the highest subsidy at 66.52 per cent of total subsidy, followed by borrowers of small business and Allied activities at 26.63 per cent and 7.85 per cent respectively. The subsidy as a percentage of loan was the highest in case of borrowers of agriculture category at 20 per cent and the lowest in the case of borrowers of allied activities at 12.75 per cent. Average loan amount borrowed is the highest in the case of small business at Rs. 16200 and the lowest in the case of agriculture at Rs.13547. The average subsidy is the highest for agriculture category followed by small business and allied activities. On the whole the average amount of loan borrowed is Rs.14302, and the average Subsidy amount is Rs.2497 which is 17.46 per cent of the average loan amount.

\subsubsection{Income Growth of Occupation-wise Sample Borrowers of select CDCCBs}

TABLE 10 depicts the growth in income of occupation-wise sample borrowers of the select CDCCBs in the district. Each borrower on an average had a growth in income of Rs.4045 which is 63.11 per cent of income before securing a loan of Rs. 6410. In the case of agriculture each borrower has a growth in income of Rs.2294 which is 46.43per cent. While considering the small business each borrower has a growth in income at Rs.6347 or 85.92 per cent and in the case of allied activities it is at Rs.7633 which is 64.64 per cent. In terms of 
amount, it is noted that among all the occupations borrowers of allied activities recorded highest growth in income followed by borrowers of small business and agriculture.

\subsubsection{Income Utilisation by Occupation-wise Sample Borrowers of Select CDCCBs}

TABLE 11 presents the occupation-wise income utilization by sample borrowers of select CDCCBs in the district. From the income earned by using loan amount, small business borrowers had spent more amounts for repayment of loan at 69.34 per cent of income followed by borrowers of allied activities and agriculture at 59.45 per cent and 53.62 per cent respectively. From the income generated by using loan borrowings, borrowers of agriculture had spent more amounts for purchase of assets at 35 per cent of income followed by borrowers of allied activities at 25.65 per cent and small business borrowers at 20.5 per cent. With regard to amount spent for ceremonies from the income earned by employing loan amount, borrowers of allied activities had spent more at 14.9 per cent followed by agriculture borrowers at 11.38 per cent and borrowers of small business at 10.16 per cent of income. As a whole the borrowers of all occupations had spent 60.8 per cent of income for loan clearance, 27.05 per cent for purchase of assets and 12.15 per cent for ceremonies.

\subsubsection{Repayment of Loans by Occupation-wise Borrowers of Select CDCCBs}

TABLE 12 presents the repayment of loans by occupation-wise sample borrowers of select CDCCBs in the district. The total loan amount of sample borrowers was Rs. 758000 of which Rs. 449500 was repaid which is 59.3 per cent and Rs. 308500 was outstanding. The borrowers of small business category stood first in repayment of loans with 69.55 per cent followed by borrowers of agriculture at 56.86 per cent and borrowers of allied activities at 41.72 per cent of loan amount. On an average each borrower has utilized loan amount of Rs.14302 out of which Rs.8481 was repaid and Rs.5281 was outstanding. The data revealed that repayment of loans is better in the case of borrowers of small business than the borrowers of all other occupations.

\section{Suggestions And Conclusions}

The analysis of the data collected from the sample beneficiaries in Chittoor District to assess the impact of NABARD's refinance operations, have facilitated to offer some suggestions presented as follows. Over the years there has been a significant increase in the access of rural inhabitants to institutional credit and, simultaneously, the role of informal agencies, including moneylenders, as a source of credit has declined. Banking procedures and behavior of bank staff must be sociable to increase the access of loans by small farmers and businessmen. Further, Proper regulatory framework is required for financial inclusion of poor people. Though there are several gaps in the present institutional credit delivery system like inadequate provision of credit to small and marginal farmers, rural artisans and small businessmen, still rural credit is still playing a critical role in developing rural economy. Through its refinance operations, NABARD has been performing with the help of banking sector to augment the credit support to production and investment purposes for the agriculture and rural development. The study reveals that the Institutional credit in Chittoor District of Andhra Pradesh State to have been increased in its quantum as the NABARD has increased the quantum of refinance to its client agencies. The analysis reveals that loan application, sanctions and utilization of loan amounts were better in allied activities than in the case of small business and agriculture. The repayment of loans is better in the case of borrowers of small business than the borrowers of all other occupations. It is noted that among all the occupations borrowers of allied activities recorded the highest growth in income followed by borrowers of small business and agriculture categories. Though the study is restricted to Chittoor district of Andhra Pradesh State, the findings of the study may be relevant to all districts or areas with similar agro-climatic and socio-economic conditions.

Table-1: Occupation-wise Loans and Subsidies to Sample Borrowers of Select CBs During the Year 2014-15

\begin{tabular}{|c|c|c|c|c|c|}
\hline SI.No. & Occupation & $\begin{array}{l}\text { No. of Sample } \\
\text { Borrowers }\end{array}$ & $\begin{array}{l}\text { Loan } \\
\text { Utilised (Rs.) }\end{array}$ & $\begin{array}{l}\text { Subsidy } \\
\text { (Rs.) }\end{array}$ & $\begin{array}{l}\text { Percentage of subsidy on } \\
\text { the loans utilized }\end{array}$ \\
\hline 1 & 2 & 3 & 4 & 5 & 6 \\
\hline 1 & $\begin{array}{l}\text { Agriculture } \\
\text { a. Percentage } \\
\text { b. Average }\end{array}$ & 34 & $\begin{array}{l}\mathbf{8 1 1 5 0 0} \\
(48.23) \\
23867\end{array}$ & $\begin{array}{l}\mathbf{6 0 8 0 0} \\
(35.48) \\
1790\end{array}$ & 7.49 \\
\hline 2 & $\begin{array}{l}\text { Small Business } \\
\text { a. Percentage } \\
\text { b. Average }\end{array}$ & 26 & $\begin{array}{l}\mathbf{5 4 3 0 0 0} \\
(32.27) \\
21128\end{array}$ & $\begin{array}{l}\mathbf{7 2 7 5 0} \\
(42.46) \\
2780\end{array}$ & 13.4 \\
\hline 3 & $\begin{array}{l}\text { Allied activities } \\
\text { a. Percentage } \\
\text { b. Average }\end{array}$ & 16 & $\begin{array}{l}\mathbf{3 2 8 0 0 0} \\
(19.49) \\
20106 \\
\end{array}$ & $\begin{array}{l}37800 \\
(22.06) \\
2363 \\
\end{array}$ & 11.52 \\
\hline 4 & $\begin{array}{l}\text { Total } \\
\text { a. Percentage } \\
\text { b. Average }\end{array}$ & 76 & $\begin{array}{l}1682500 \\
(100) \\
10455\end{array}$ & $\begin{array}{l}171350 \\
(100) \\
2255 \\
\end{array}$ & 10.18 \\
\hline
\end{tabular}

Source: Field Survey.

Notes: Figures in parentheses are percentages to column totals. 
Table-2: Income Growth of Occupation-wise Sample Borrowers by Using Loans from Select Commercial Bank Branches during 2014-15

\begin{tabular}{|c|c|c|c|c|c|c|}
\hline \multirow[b]{2}{*}{$\begin{array}{l}\text { Sl. } \\
\text { No. }\end{array}$} & \multirow[t]{2}{*}{ Occupation } & \multirow{2}{*}{$\begin{array}{l}\text { No. of Sample } \\
\text { Borrowers }\end{array}$} & \multicolumn{2}{|c|}{ Annual Income (Rs.) } & \multirow{2}{*}{$\begin{array}{l}\text { Income Growth } \\
\text { (Rs.) }\end{array}$} & \multirow{2}{*}{$\begin{array}{ll}\text { Col.6 } & \text { as } \\
\text { Percentage } & \text { of } \\
\text { Col.4 } & \end{array}$} \\
\hline & & & Before & After & & \\
\hline 1 & 2 & 3 & 4 & 5 & $6(5-4)$ & 7 \\
\hline 1 & $\begin{array}{l}\text { Agriculture } \\
\text { a. Total } \\
\text { b. Average }\end{array}$ & 34 & $\begin{array}{l}292250 \\
(8596)\end{array}$ & $\begin{array}{l}417500 \\
(12279)\end{array}$ & $\begin{array}{l}125250 \\
(3684)\end{array}$ & 42.86 \\
\hline 2 & $\begin{array}{l}\text { Small Business } \\
\text { a. Total } \\
\text { b. Average }\end{array}$ & 26 & $\begin{array}{l}309650 \\
(11910)\end{array}$ & $\begin{array}{l}472650 \\
(18179)\end{array}$ & $\begin{array}{l}163000 \\
(6269)\end{array}$ & 52.64 \\
\hline 3 & $\begin{array}{l}\text { Allied activities } \\
\text { a. Total } \\
\text { b. Average }\end{array}$ & 16 & $\begin{array}{l}207250 \\
(12953)\end{array}$ & $\begin{array}{l}284750 \\
(17797)\end{array}$ & $\begin{array}{l}77500 \\
(4844)\end{array}$ & 37.39 \\
\hline 4 & $\begin{array}{l}\text { All } \\
\text { a. Total } \\
\text { b. Average } \\
\end{array}$ & 76 & $\begin{array}{l}809150 \\
(10647) \\
\end{array}$ & $\begin{array}{l}1174900 \\
(15459)\end{array}$ & $\begin{array}{l}365750 \\
(4813) \\
\end{array}$ & 45.20 \\
\hline
\end{tabular}

Source: Field Survey.

Table-3: Income Utilization by Occupation-wise Sample Borrowers of Select Commercial Bank Branches during 2014-15

\begin{tabular}{|l|l|l|l|l|l|l|}
\hline \multirow{2}{*}{ Sl. No. } & Occupation & \multirow{2}{*}{$\begin{array}{l}\text { No. of Sample } \\
\text { Borrowers }\end{array}$} & \begin{tabular}{l} 
Income (Rs.) \\
\cline { 4 - 7 }
\end{tabular} & $\mathbf{3}$ & $\begin{array}{l}\text { Percentage of Income Utilisation for } \\
\text { Repayment }\end{array}$ & \multicolumn{2}{|l|}{ Purchase of Assets } & Ceremonies \\
\hline $\mathbf{1}$ & $\mathbf{2}$ & 34 & $\begin{array}{l}125250 \\
(100)\end{array}$ & 62.42 & 25.08 & $\mathbf{6}$ \\
\hline 1 & Agriculture & $\begin{array}{l}163000 \\
(100)\end{array}$ & 90.58 & 5.01 & 4.41 \\
\hline 2 & Small Business & 26 & $\begin{array}{l}77500 \\
(100)\end{array}$ & 73.00 & 19.38 & 7.62 \\
\hline 3 & Allied Activities & 16 & $\begin{array}{l}\mathbf{3 6 5 7 5 0} \\
(\mathbf{1 0 0})\end{array}$ & $\mathbf{7 5 . 3 3}$ & $\mathbf{1 6 . 4 9}$ & $\mathbf{8 . 1 8}$ \\
\hline $\mathbf{4}$ & All & $\mathbf{7 6}$ & & & \\
\hline
\end{tabular}

Source: Field Survey

Note: Figures in parenthesis of $4^{\text {th }}$ column are percentage totals of respective rows

Table-4: Repayments of Loans by Occupation-wise Sample Borrowers of Select Commercial Banks Branches during the Year 2014-15

\begin{tabular}{|c|c|c|c|c|c|c|}
\hline \multirow[t]{2}{*}{ Sl.No. } & \multirow[t]{2}{*}{ Occupation } & \multirow[t]{2}{*}{$\begin{array}{l}\text { No. of Sample } \\
\text { Borrowers }\end{array}$} & \multicolumn{3}{|c|}{$\begin{array}{l}\text { Loan amount } \\
\text { (Rs.) }\end{array}$} & \multirow{2}{*}{$\begin{array}{l}\text { Col.5 as } \\
\text { percentage } \\
\text { of Col.4 }\end{array}$} \\
\hline & & & Utilized & Repayment & Out standings & \\
\hline 1 & 2 & 3 & 4 & 5 & 6 & 7 \\
\hline 1 & Agriculture & 34 & $\begin{array}{l}811500 \\
(23868) \\
\end{array}$ & $\begin{array}{l}554500 \\
(16309) \\
\end{array}$ & $\begin{array}{l}257000 \\
(7559) \\
\end{array}$ & 68.33 \\
\hline 2 & $\begin{array}{l}\text { Small } \\
\text { Business }\end{array}$ & 26 & $\begin{array}{l}543000 \\
(20885)\end{array}$ & $\begin{array}{l}289800 \\
(11146)\end{array}$ & $\begin{array}{l}253200 \\
(9738)\end{array}$ & 53.37 \\
\hline 3 & $\begin{array}{l}\text { Allied } \\
\text { Activities }\end{array}$ & 16 & $\begin{array}{l}328000 \\
(20500)\end{array}$ & $\begin{array}{l}162000 \\
(10125)\end{array}$ & $\begin{array}{l}166000 \\
(10375)\end{array}$ & 49.39 \\
\hline 4 & Total & 76 & $\begin{array}{l}1682500 \\
(22138)\end{array}$ & $\begin{array}{l}\text { 1006300 } \\
(13241)\end{array}$ & $\begin{array}{l}\mathbf{6 7 6 2 0 0} \\
(8897)\end{array}$ & 59.81 \\
\hline
\end{tabular}

Source: Field Survey.

Note: Figures in parentheses are the average.

Table-5: Occupation-wise Loans and Subsidies to Sample Borrowers of Select SGBs During the Year 2014-15

\begin{tabular}{|c|c|c|c|c|c|}
\hline SI.No. & Occupation & $\begin{array}{l}\text { No. of Sample } \\
\text { Borrowers }\end{array}$ & $\begin{array}{ll}\text { Loan } & \text { Utilized } \\
\text { (Rs.) } & \end{array}$ & $\begin{array}{l}\text { Subsidy } \\
\text { (Rs.) }\end{array}$ & $\begin{array}{l}\text { Percentage of subsidy on } \\
\text { the loans utilized }\end{array}$ \\
\hline 1 & 2 & 3 & 4 & 5 & 6 \\
\hline 1 & $\begin{array}{l}\text { Agriculture } \\
\text { a. Percentage } \\
\text { b. Average }\end{array}$ & 38 & $\begin{array}{l}489600 \\
(52.99) \\
12884\end{array}$ & $\begin{array}{l}95500 \\
(60.39) \\
2513\end{array}$ & 19.51 \\
\hline 2 & $\begin{array}{l}\text { Small Business } \\
\text { a. Percentage } \\
\text { b. Average }\end{array}$ & 18 & $\begin{array}{l}267000 \\
(28.90) \\
14833\end{array}$ & $\begin{array}{l}41750 \\
(26.40) \\
2319\end{array}$ & 15.64 \\
\hline
\end{tabular}


Impact of NABARD's Refinance Operations on the Beneficiaries in Chittoor District of

\begin{tabular}{|l|l|l|l|l|l|}
\hline 3 & $\begin{array}{l}\text { Allied activities } \\
\text { a. Percentage } \\
\text { b. Average }\end{array}$ & 7 & $\begin{array}{l}167400 \\
(18.12) \\
23914\end{array}$ & $\begin{array}{l}20900 \\
(13.22) \\
2986\end{array}$ & 12.49 \\
\hline $\mathbf{4}$ & $\begin{array}{l}\text { Total } \\
\text { a. Percentage } \\
\text { b. Average }\end{array}$ & $\mathbf{6 3}$ & $\begin{array}{l}\mathbf{9 2 4 0 0 0} \\
\mathbf{( 1 0 0 )}\end{array}$ & $\begin{array}{l}\mathbf{1 5 8 1 5 0} \\
(\mathbf{1 0 0}) \\
\mathbf{2 5 1 0}\end{array}$ & $\mathbf{1 7 . 1 2}$ \\
\hline
\end{tabular}

Source: Field Survey.

Notes: Figures in parentheses are percentages to column totals.

Table-6: Income Growth of Occupation-wise Sample Borrowers by Using Loans from Select SGBs during 2014-15

\begin{tabular}{|c|c|c|c|c|c|c|}
\hline \multirow{2}{*}{$\begin{array}{l}\text { Sl. } \\
\text { No. }\end{array}$} & \multirow[t]{2}{*}{ Occupation } & \multirow{2}{*}{$\begin{array}{l}\text { No. of Sample } \\
\text { Borrowers }\end{array}$} & \multicolumn{2}{|c|}{ Annual Income (Rs.) } & \multirow{2}{*}{$\begin{array}{l}\text { Income Growth } \\
\text { (Rs.) }\end{array}$} & \multirow{2}{*}{$\begin{array}{l}\text { Col.6 as Percentage } \\
\text { of Col.4 }\end{array}$} \\
\hline & & & Before & After & & \\
\hline 1 & 2 & 3 & 4 & 5 & $6(5-4)$ & 7 \\
\hline 1 & $\begin{array}{l}\text { Agriculture } \\
\text { a. Total } \\
\text { b. Average }\end{array}$ & 38 & $\begin{array}{l}129650 \\
(3412)\end{array}$ & $\begin{array}{l}222200 \\
(5847)\end{array}$ & $\begin{array}{l}92550 \\
(2436)\end{array}$ & 71.38 \\
\hline 2 & $\begin{array}{l}\text { Small Business } \\
\text { a. Total } \\
\text { b. Average }\end{array}$ & 18 & $\begin{array}{l}135400 \\
(7522)\end{array}$ & $\begin{array}{l}241000 \\
(13389)\end{array}$ & $\begin{array}{l}105600 \\
(5867)\end{array}$ & 77.99 \\
\hline 3 & $\begin{array}{l}\text { Allied activities } \\
\text { a. Total } \\
\text { b. Average }\end{array}$ & 7 & $\begin{array}{l}74050 \\
(10579)\end{array}$ & $\begin{array}{l}134300 \\
(19186)\end{array}$ & $\begin{array}{l}60250 \\
(8607)\end{array}$ & 81.36 \\
\hline 4 & $\begin{array}{l}\text { All } \\
\text { a. Total } \\
\text { b. Average }\end{array}$ & 63 & $\begin{array}{l}\text { 339100 } \\
(5383)\end{array}$ & $\begin{array}{l}\mathbf{5 9 7 5 0 0} \\
(9484)\end{array}$ & $\begin{array}{l}\mathbf{2 5 8 4 0 0} \\
(4102)\end{array}$ & 76.20 \\
\hline
\end{tabular}

Source: Field Survey.

Table-7: Income Utilisation by Occupation-wise Sample Borrowers of Select SGBs During 2014-15

\begin{tabular}{|c|c|c|c|c|c|c|}
\hline \multirow[b]{2}{*}{$\begin{array}{l}\text { SI. } \\
\text { No. }\end{array}$} & \multirow[t]{2}{*}{ Occupation } & \multirow[b]{2}{*}{$\begin{array}{l}\text { No. of Sample } \\
\text { Borrowers }\end{array}$} & \multirow{2}{*}{$\begin{array}{l}\text { Income } \\
\text { (Rs.) }\end{array}$} & \multicolumn{3}{|c|}{ Percentage of Income Utilisation for } \\
\hline & & & & Loan Repayment & $\begin{array}{ll}\text { Purchase of } \\
\text { Assets }\end{array}$ & Ceremonies \\
\hline 1 & 2 & 3 & 4 & 5 & 6 & 7 \\
\hline 1 & Agriculture & 38 & $\begin{array}{l}92550 \\
(100) \\
\end{array}$ & 52.26 & 34.50 & 13.24 \\
\hline 2 & Small Business & 18 & $\begin{array}{l}105600 \\
(100)\end{array}$ & 79.43 & 15.46 & 5.11 \\
\hline 3 & Allied Activities & 7 & $\begin{array}{l}60250 \\
(100)\end{array}$ & 56.98 & 43.02 & - \\
\hline 4 & All & 63 & $\begin{array}{l}258400 \\
(100)\end{array}$ & 62.89 & 30.99 & 6.12 \\
\hline
\end{tabular}

Source: Field Survey

Note: Figures in parenthesis of $4^{\text {th }}$ column are percentage totals of respective rows

Table-8: Repayments of Loans by Occupation-wise Sample Borrowers of Select SGBs During the Year 2014-

\begin{tabular}{|c|c|c|c|c|c|c|}
\hline \multirow[b]{2}{*}{ SI.No. } & \multirow[t]{2}{*}{ Occupation } & \multirow{2}{*}{$\begin{array}{l}\text { No. of Sample } \\
\text { Borrowers }\end{array}$} & \multicolumn{3}{|c|}{ Loan amount (Rs.) } & \multirow{2}{*}{$\begin{array}{l}\text { Col.5 as percentage } \\
\text { of Col.4 }\end{array}$} \\
\hline & & & Utilized & Repayment & Out standings & \\
\hline 1 & 2 & 3 & 4 & 5 & 6 & 7 \\
\hline 1 & Agriculture & 38 & $\begin{array}{l}489600 \\
(12884)\end{array}$ & $\begin{array}{l}336500 \\
(8855)\end{array}$ & $\begin{array}{l}153100 \\
(4029)\end{array}$ & 68.73 \\
\hline 2 & Small Business & 18 & $\begin{array}{l}267000 \\
(14833)\end{array}$ & $\begin{array}{l}192400 \\
(10689)\end{array}$ & $\begin{array}{l}74600 \\
(4144)\end{array}$ & 72.06 \\
\hline 3 & Allied Activities & 7 & $\begin{array}{l}167400 \\
(23914)\end{array}$ & $\begin{array}{l}114800 \\
(16400)\end{array}$ & $\begin{array}{l}52600 \\
(7514)\end{array}$ & 68.58 \\
\hline 4 & Total & 63 & $\begin{array}{l}924000 \\
(14667)\end{array}$ & $\begin{array}{l}643700 \\
(10217)\end{array}$ & $\begin{array}{l}280300 \\
(4449)\end{array}$ & 69.66 \\
\hline
\end{tabular}

Source: Field Survey.

Note: Figures in parentheses are the average. 
Impact of NABARD's Refinance Operations on the Beneficiaries in Chittoor District of

Table-9:Occupation-wise Loans and Subsidies to Sample Borrowers of Select CDCCBs During the Year 2014-15

\begin{tabular}{|c|c|c|c|c|c|}
\hline Sl.No. & Occupation & $\begin{array}{l}\text { No. of Sample } \\
\text { Borrowers }\end{array}$ & $\begin{array}{ll}\text { Loan Utilized } \\
\text { (Rs.) }\end{array}$ & $\begin{array}{l}\text { Subsidy } \\
\text { (Rs.) }\end{array}$ & $\begin{array}{l}\text { Percentage of subsidy on } \\
\text { the loans utilized }\end{array}$ \\
\hline 1 & 2 & 3 & 4 & 5 & 6 \\
\hline 1 & $\begin{array}{l}\text { Agriculture } \\
\text { a. Percentage }\end{array}$ & 32 & $\begin{array}{l}433500 \\
(57.19)\end{array}$ & $\begin{array}{l}86700 \\
(66.52)\end{array}$ & 20.00 \\
\hline 2 & $\begin{array}{l}\text { Small } \\
\text { Business }\end{array}$ & 15 & $\begin{array}{l}243000 \\
(32.06)\end{array}$ & $\begin{array}{l}35235 \\
(26.63)\end{array}$ & 14.50 \\
\hline 3 & $\begin{array}{l}\text { Allied } \\
\text { activities }\end{array}$ & 6 & $\begin{array}{l}81500 \\
(10.75)\end{array}$ & $\begin{array}{l}10390 \\
(7.85)\end{array}$ & 12.75 \\
\hline 4 & $\begin{array}{l}\text { Total } \\
\text { a. Percentage } \\
\text { b. Average }\end{array}$ & 53 & $\begin{array}{l}758000 \\
(100) \\
14302\end{array}$ & $\begin{array}{l}132325 \\
(100) \\
2497\end{array}$ & 17.46 \\
\hline
\end{tabular}

Source: Field Survey.

Notes: Figures in parentheses are percentages to column totals.

Table-10: Income Growth of Occupation-wise Sample Borrowers by Using Loans from Select CDCCBs during 2014-15

\begin{tabular}{|c|c|c|c|c|c|c|}
\hline \multirow[b]{2}{*}{ Sl. No. } & \multirow[t]{2}{*}{ Occupation } & \multirow{2}{*}{$\begin{array}{l}\text { No. of Sample } \\
\text { Borrowers }\end{array}$} & \multicolumn{2}{|c|}{ Annual Income (Rs.) } & \multirow{2}{*}{$\begin{array}{l}\text { Income Growth } \\
\text { (Rs.) }\end{array}$} & \multirow{2}{*}{$\begin{array}{l}\text { Col.6 as Percentage } \\
\text { of Col.4 }\end{array}$} \\
\hline & & & Before & After & & \\
\hline 1 & 2 & 3 & 4 & 5 & $6(5-4)$ & 7 \\
\hline 1 & $\begin{array}{l}\text { Agriculture } \\
\text { a. Total } \\
\text { b. Average } \\
\end{array}$ & 32 & $\begin{array}{l}158100 \\
(4941)\end{array}$ & $\begin{array}{l}231500 \\
(7234)\end{array}$ & $\begin{array}{l}73400 \\
(2294)\end{array}$ & 46.43 \\
\hline 2 & $\begin{array}{l}\text { Small Business } \\
\text { a. Total } \\
\text { b. Average }\end{array}$ & 15 & $\begin{array}{l}110800 \\
(7387)\end{array}$ & $\begin{array}{l}206000 \\
(13733)\end{array}$ & $\begin{array}{l}95200 \\
(6347)\end{array}$ & 85.92 \\
\hline 3 & $\begin{array}{l}\text { Allied activities } \\
\text { a. Total } \\
\text { b. Average }\end{array}$ & 6 & $\begin{array}{l}70850 \\
(11808)\end{array}$ & $\begin{array}{l}116650 \\
(19442)\end{array}$ & $\begin{array}{l}45800 \\
(7633)\end{array}$ & 64.64 \\
\hline 4 & $\begin{array}{l}\text { All } \\
\text { a. Total } \\
\text { b. Average }\end{array}$ & 53 & $\begin{array}{l}339750 \\
(6410)\end{array}$ & $\begin{array}{l}554150 \\
(10456)\end{array}$ & $\begin{array}{l}214400 \\
(4045)\end{array}$ & 63.11 \\
\hline
\end{tabular}

Source: Field Survey.

Table-11: Income Utilisation by Occupation-wise Sample Borrowers of Select CDCCBs During the Year

\begin{tabular}{|c|c|c|c|c|c|c|}
\hline \multirow[b]{2}{*}{ Sl. No. } & \multirow[t]{2}{*}{ Occupation } & \multirow[b]{2}{*}{$\begin{array}{l}\text { No. of Sample } \\
\text { Borrowers }\end{array}$} & \multirow{2}{*}{$\begin{array}{l}\text { Income } \\
\text { (Rs.) }\end{array}$} & \multicolumn{3}{|c|}{ Percentage of Income Utilisation for } \\
\hline & & & & Loan Repayment & $\begin{array}{l}\text { Purchase of } \\
\text { Assets }\end{array}$ & Ceremonies \\
\hline 1 & 2 & 3 & 4 & 5 & 6 & 7 \\
\hline 1 & Agriculture & 32 & $\begin{array}{l}73400 \\
(100)\end{array}$ & 53.62 & 35.00 & 11.38 \\
\hline 2 & Small Business & 15 & $\begin{array}{l}95200 \\
(100)\end{array}$ & 69.34 & 20.50 & 10.16 \\
\hline 3 & $\begin{array}{l}\text { Allied } \\
\text { Activities }\end{array}$ & 6 & $\begin{array}{l}45800 \\
(100)\end{array}$ & 59.45 & 25.65 & 14.90 \\
\hline 4 & All & 53 & $\begin{array}{l}214400 \\
(100)\end{array}$ & 60.80 & 27.05 & 12.15 \\
\hline
\end{tabular}

Source: Field Survey

Note: Figures in parenthesis of $4^{\text {th }}$ column are percentage totals of respective rows

Table-12: Repayments of Loans by Occupation-wise Sample Borrowers of Select CDCCBs during the Year 2014-15

\begin{tabular}{|c|c|c|c|c|c|c|}
\hline \multirow[t]{2}{*}{ Sl.No. } & \multirow[t]{2}{*}{ Occupation } & \multirow[t]{2}{*}{$\begin{array}{l}\text { No. of Sample } \\
\text { Borrowers }\end{array}$} & \multicolumn{3}{|c|}{$\begin{array}{l}\text { Loan amount } \\
\text { (Rs.) }\end{array}$} & \multirow{2}{*}{$\begin{array}{l}\text { Col.5 as } \\
\text { percentage } \\
\text { of Col.4 }\end{array}$} \\
\hline & & & Utilized & Repayment & Out standings & \\
\hline 1 & 2 & 3 & 4 & 5 & 6 & 7 \\
\hline 1 & Agriculture & 32 & $\begin{array}{l}433500 \\
(13547) \\
\end{array}$ & $\begin{array}{l}246500 \\
(7703)\end{array}$ & $\begin{array}{l}187000 \\
(5844)\end{array}$ & 56.86 \\
\hline 2 & Small Business & 15 & $\begin{array}{l}243000 \\
(16200)\end{array}$ & $\begin{array}{l}169000 \\
(11267)\end{array}$ & $\begin{array}{l}74000 \\
(4933)\end{array}$ & 69.55 \\
\hline 3 & Allied Activities & 6 & $\begin{array}{l}81500 \\
(13583) \\
\end{array}$ & $\begin{array}{l}34000 \\
(5667) \\
\end{array}$ & $\begin{array}{l}47500 \\
(7917) \\
\end{array}$ & 41.72 \\
\hline 4 & Total & 53 & $\begin{array}{l}758000 \\
(14302) \\
\end{array}$ & $\begin{array}{l}449500 \\
(8481)\end{array}$ & $\begin{array}{l}\mathbf{3 0 8 5 0 0} \\
(\mathbf{5 8 2 1}) \\
\end{array}$ & 59.30 \\
\hline
\end{tabular}

Source: Field Survey.

Note: Figures in parentheses are the average. 


\section{Books}

\section{References}

[1]. Ranjula Bali Swain, The microfinance impact (Abingdon, Oxon : Routledge 2012).

\section{Journal Papers}

[2]. P S Rao, NABARD and RBI A 30-year legacy being upturned, Economic \& political weekly, No.38, Vol. XLVII, September 2012, 27-30.

[3]. Anwarul Hoda, and Prerna Terway, Credit Policy for Agriculture in India - An Evaluation, , Indian Council for Research on International Economic Relations (ICRIER), Working Paper.302, june.2015, 28-34.

[4]. Dr.V.J.R Emerlson Mosses and Mr. G. Krishnamoorhty, Impact of Microfinance and SHG - An Overview, EPRA International Journal of Economic and Business Review, Vol.2, Issue.8, August 2014, 71-76.

[5]. R. Uma Devi and S. R. K. Govt, The Role of Credit Co-Operatives in the Agricultural Development of Andhra Pradesh, India, International Journal of Cooperative Studies, Vol. 1, No. 2, 2012, 55-64.

[6]. Shahin Razi, Continued Rural Agenda, Kurukshetra, Vol.63, No.6, Apr 2015, 07-10.

[7]. Veerpaul Kaur Maan and Amritpal Singh(2013), "Role of NABARD and RBI in Agricultural Sector Growth", International Journal of Emerging Research in Management \&Technology, Vol.2, Issue.3, March 2013, 39-46. 